Original Paper

Section: Food Quality and Functionality

\title{
Selected Properties of Single- and Double-Extruded Potato Starch
}

\author{
Ewa Tomaszewska-Ciosk, Antoni Golachowski, Wioletta Drożdż*, \\ Tomasz Boruczkowski, Hanna Boruczkowska, Ewa Zdybel \\ Department of Agricultural Technology and Storage, Wroctaw University of Environmental \\ and Life Sciences, C.K. Norwida 25, 50-375 Wroctaw, Poland
}

Key words: potato starch, extrusion, single- and double-extruded starch

The aim of this study was to determine the properties of single- and double-extruded starch. Single-extruded starch was obtained using a single screw extruder at temperatures of $50-60-70^{\circ} \mathrm{C}, 90-100-120^{\circ} \mathrm{C}$ and $140-150-170^{\circ} \mathrm{C}$, whereas double-extruded starch was obtained after grinding each of the three single-extruded starch samples and their re-extrusion at temperatures of $90-100-120^{\circ} \mathrm{C}$ and $140-150-170^{\circ} \mathrm{C}$. The samples were determined for solubility in water and absorption capacity at a temperature of 30 and $80^{\circ} \mathrm{C}$. Flow curves of the prepared pastes were plotted. Properties of double-extruded potato starch differed from those of the single-extruded starch. The study shows that the extent and direction of these changes depended on the number of the conducted extrusion processes and on their temperatures. Each successive process of extrusion and the increase in process temperatures resulted in an increased solubility of the preparations and a decrease in their water absorption capacity. Values of the rheological properties of pastes prepared from double-extruded potato starch were lower than those of the pastes produced from single-extruded potato starch.

\section{INTRODUCTION}

Extrusion is a mechanical and thermal process, in which within a considerably short time a raw material (carbohydrate, protein) is exposed to temperature, mechanical forces and pressure and then transformed from flour into a plastic mass. Afterwards, as a result of a rapid decrease in pressure and water evaporation, a new product of a characteristic texture and shape is being formed.

The process of extrusion constitutes nowadays a widely applied technology as the parameters of this process, such as temperature, pressure and intensity of mechanical forces action, afford the possibility of modeling product properties, changing them completely as compared to these of the raw material [Jamroz et al., 1998; Gambuś et al., 1999; Rzedzicki \& Zarzycki, 2005]. The extrusion evokes disruption of the structure of starch granules, changes in the spatial arrangement of starch chains, a change in the degree of starch crystallinity and partial molecular degradation [Gambuś et al., 1999; Nabeshima \& Grossmann, 2001]. The process of extrusion increases water solubility and absorption capacity of starch [Śmietana et al., 1996; Wójtowicz, 2005], and its susceptibility to the action of enzymes [Hagenimana et al., 2006; Sun et al., 2006], as well as decreases its viscosity [Gonzáles et al., 2006]. Changes in these properties are due to, among other things, a damage to the crystalline structure and defragmentation of starch

\footnotetext{
* Corresponding author: Tel.: + 487132077 66;

E-mail: ewatc@wnoz.up.wroc.pl (W. Drożdż)
}

chains during extrusion. The molecular mass of particular starch chains is decreasing in the exponential function along with an increase in the specific mechanical energy (SME). Both the mechanical and thermal energy lead to the destruction of hydrogen bonds between neighbouring chains in a starch structure and to disruption of these chains. These changes are more distinct in the case of amylopectin than amylose. The average molecular mass of amylose during the extrusion process decreases 1.5-fold, while in the case of amylopectin - 15-fold [Lai \& Kokini, 1991; Della Valle et al., 1995].

The application of this process enabled obtaining a number of novel preparations, which, with regard to their interesting properties, have been applied in various industries, including the food industry. A range of products obtained through the extrusion process was considerably broadened by applying starch mixtures with various chemical substances in the process of extrusion. A variety of reactions are conducted in extruders with different chemical compounds being added to starch, e.g.: phosphorylation, acetylation, oxidation and many others. Products obtained as a result of coupling chemical methods of starch modification with the extrusion process have new interesting properties, being diametrically different from those of products obtained with conventional methods [Ganjyal \& Hanna, 2004; Drożdż \& Tomaszewska-Ciosk, 2007; Zięba et al., 2007].

New, innovative methods of starch modification, which would enable formulating products with new applicable attributes are constantly searched for. This may be achieved through the application of starch materials that have not 
been in use previously [Alves et al., 1999; Kőksel et al., 2004], chemical substances [Nabeshima \& Grossmann, 2001; Singh \& Smith, 1997] as well as various conditions of the processes, including: temperature, moisture content of the extruded material, type of a softening agent, the value of pressure and mechanical forces [Jamroz et al., 1998; Gambuś et al., 1999; Rzedzicki \& Zarzycki, 2005; Singh et al., 2007].

The determination of changes in the functional properties of starch preparations obtained as a result of extruding once extruded material appears also significant. Probably, the application of a double extrusion process will enable obtaining original starch preparations [Kollengode et al., 1996; Thymi et al., 2005].

The aim of this study was, therefore, to determine properties of starch subjected to single- and double-extrusion process and to determine the effect of parameters of both extrusion processes on the properties of the resultant extrudates.

\section{MATERIAL AND METHODS}

\section{Production of preparations}

The study was conducted with potato starch produced by Przedsiębiorstwo Przemysłu Ziemniaczanego S.A. in Niechlów, Poland.

Starch was adjusted to a moisture content of $25 \%$ and subjected to the process of extrusion in a single-screw extruder type $20 \mathrm{DN}$ by Brabender, with a compression ratio of 2:1 and a round nozzle $3 \mathrm{~mm}$ in diameter. The single screw was rotating at $80 \mathrm{rpm}$ and the feeder at $30 \mathrm{rpm}$. The process of extrusion was carried out in three temperature variants, in which the temperatures of the first and second section of the extruder, and of extruder head were as follows: 50-60$-70^{\circ} \mathrm{C}, 90-100-120^{\circ} \mathrm{C}$ and $140-150-170^{\circ} \mathrm{C}$, respectively.

The produced preparations were ground in a laboratory knife mill Pulversisette 19 by Fritsche to average particle diameter of $1 \mathrm{~mm}$. Part of the extrudates was ground to the average particle diameter of $400 \mu \mathrm{m}$ using a laboratory mill. The remaining part was brought to $21 \%$ moisture content and subjected to the second extrusion using a screw with a compression ratio of 2:1 and a round nozzle of $3 \mathrm{~mm}$ in diameter. The process of second extrusion was conducted in two temperature variants, in which the temperatures of the first and second section of the extruder and extruder head were as follows: $90-100-120^{\circ} \mathrm{C}$ and $140-150-170^{\circ} \mathrm{C}$, respectively. The rotations of the screw were $80 \mathrm{rpm}$ and these of the feeder $60 \mathrm{rpm}$. The modified preparations obtained as a result of the second extrusion were ground to the average particle diameter of $400 \mu \mathrm{m}$.

\section{Analyses}

The preparations produced in the process of single and double extrusion after grinding were determined for:

- water solubility and absorption capacity at a temperature of $30^{\circ} \mathrm{C}$ and $80^{\circ} \mathrm{C}$ [Richter et al., 1968]

- viscosity of a $10 \%$ suspension of extruded starch heated to $95^{\circ} \mathrm{C}$ and kept at this temperature for $30 \mathrm{~min}$, with constant and intensive stirring. Viscosity was determined by the use of an RS 50 Rhoestress rotational viscometer by Haake.
Flow curves of the produced pastes were determined at $50^{\circ} \mathrm{C}$, at the shear rate of $0-300 \mathrm{~s}^{-1}$, applying Z38 type coaxial cylinders with a single gap as a measuring element. The flow curves obtained were described by means of two rheological models:

$$
\begin{array}{ll}
\tau=K \cdot \dot{\gamma}^{n} & \text { (1) Ostwald de Waele: } \\
\tau=\tau_{0 \mathrm{C}}^{0,5}+\left(\eta_{\mathrm{C}} \cdot \gamma\right)^{0,5} & \text { (2) Casson: }
\end{array}
$$

where: $\tau$ - shear stress $[\mathrm{Pa}], \mathrm{K}$ - consistency coefficient $\left[\mathrm{Pa} \cdot \mathrm{s}^{\mathrm{n}}\right.$ ], $\dot{\gamma}$ - shear rate $\left[\mathrm{s}^{-1}\right], n$ - flow behaviour index, $\tau_{0 \mathrm{C}}-$ yield stress $[\mathrm{Pa}]$, and $\eta_{\mathrm{C}}-$ Casson's plastic viscosity [Pa·s].

The above rheological models were selected on the basis of the degree of their fit to the flow curves obtained. The coefficient of determination $\left(r^{2}\right)$ in all the examined cases was above 0.99 .

The results of the analyses were statistically evaluated with one-way and two-way analysis of variance, homogenous groups were determined with Duncan's test at the confidence level of $p<0.05$ using a Statistica v. 7.1 software.

\section{RESULTS AND DISCUSSION}

Tables 1 and 2 present the values of water solubility of starch subjected to single- and double-extrusion determined in water with a temperature of $30^{\circ} \mathrm{C}$ and $80^{\circ} \mathrm{C}$, adopting these temperatures as typical of respectively "cold-soluble" and "hot-soluble" preparations. At both measurement temperatures, the increasing temperature of the first extrusion was accompanied by an increase in the mean value of this parameter. Starch extruded at the temperature of 50$-60-70^{\circ} \mathrm{C}$ was characterised by the lowest water solubility $\left(82.60 \%\right.$ at $30^{\circ} \mathrm{C}$ and $90.67 \%$ at $80^{\circ} \mathrm{C}$ ), whereas starch whose first extrusion was conducted in the most extreme conditions - by the highest water solubility $\left(92.31 \%\right.$ at $30^{\circ} \mathrm{C}$ and $95.58 \%$ at $80^{\circ} \mathrm{C}$ ). Each of the applied temperatures of the first extrusion process resulted in a significant increase of the water solubility of the preparations obtained as a result of this process. Also, the second extrusion and its both temperature variants were the factors causing statistically significant changes in starch solubility. The lowest solubility in water was recorded when examining single-extruded starch $(79.76 \%$ at $30^{\circ} \mathrm{C}$ and $88.17 \%$ at $80^{\circ} \mathrm{C}$ ). The second extrusion significantly increased the value of this parameter, i.e. along with an increase in the temperature of the second extrusion the water solubility of the obtained preparations was also observed to increase. In the case of starch obtained at the lower temperature of the second extrusion it accounted for $88.49 \%$ - at measurement temperature of $30^{\circ} \mathrm{C}$ and for $93.89 \%$ - at measurement temperature $80^{\circ} \mathrm{C}$, as well as for $94.37 \%$ and $97.08 \%$, respectively, in the case of starch extruded at the temperature of the second extrusion process reaching $140-150-170^{\circ} \mathrm{C}$.

High solubility of starch after the extrusion process is the evidence of the damage to the structure of starch granules being the result of the mechanical damage of bonds in starch chains, disruption of hydrogen bonds as well as overcoming van der Waals forces [Guha et al., 1997]. During the process of extrusion, starch loses its natural crystalline 
TABLE 1. Water solubility at the temperature of $30^{\circ} \mathrm{C}$ of preparations obtained in single and double extrusion process.

\begin{tabular}{|c|c|c|c|c|c|}
\hline \multicolumn{6}{|c|}{ Water solubility at the temperature of $30^{\circ} \mathrm{C}(\%)$} \\
\hline \multirow{2}{*}{\multicolumn{2}{|c|}{ Temperature of first extrusion process }} & \multicolumn{2}{|c|}{ Temperature of second extrusion process } & \multirow{2}{*}{\multicolumn{2}{|c|}{ Mean }} \\
\hline & & $90-100-120^{\circ} \mathrm{C}$ & $140-150-170^{\circ} \mathrm{C}$ & & \\
\hline $50-60-70^{\circ} \mathrm{C}$ & 73.00 & 82.20 & 92.60 & 82.60 & \\
\hline $90-100-120^{\circ} \mathrm{C}$ & 80.13 & 90.01 & 93.02 & 87.72 & $\mathrm{NIR}=2.04$ \\
\hline $140-150-170^{\circ} \mathrm{C}$ & 86.15 & 93.27 & 97.50 & 92.31 & \\
\hline \multirow[t]{2}{*}{ Mean } & 79.76 & 88.49 & 94.37 & & \\
\hline & & $\mathrm{NIR}=1.46$ & & & \\
\hline
\end{tabular}

TABLE 2. Water solubility at the temperature of $80^{\circ} \mathrm{C}$ of preparations obtained in single and double extrusion process.

\begin{tabular}{|c|c|c|c|c|c|}
\hline \multicolumn{6}{|c|}{ Water solubility at the temperature of $80^{\circ} \mathrm{C}(\%)$} \\
\hline \multirow{2}{*}{ Temperature of first extrusion process } & & \multicolumn{2}{|c|}{ Temperature of second extrusion process } & \multirow{2}{*}{\multicolumn{2}{|c|}{ Mean }} \\
\hline & & $90-100-120^{\circ} \mathrm{C}$ & $140-150-170^{\circ} \mathrm{C}$ & & \\
\hline $50-60-70^{\circ} \mathrm{C}$ & 86.01 & 90.36 & 95.65 & 90.67 & \\
\hline $90-100-120^{\circ} \mathrm{C}$ & 87.90 & 93.51 & 97.24 & 92.88 & $\mathrm{NIR}=1.57$ \\
\hline $140-150-170^{\circ} \mathrm{C}$ & 90.61 & 97.79 & 98.35 & 95.58 & \\
\hline \multirow[t]{2}{*}{ Mean } & 88.17 & 93.89 & 97.08 & & \\
\hline & & $\mathrm{NIR}=1.7$ & & & \\
\hline
\end{tabular}

structure, undergoes partial molecular degradation and shifts into a gel form. In the field of shear forces in an extruder, the starch chains and, in particular these of branched fractions, might be partly disintegrated to maltodextrins characterised by a higher water solubility compared to the non-extruded starch [Singh et al., 2007]. The recorded increase of solubility after the second extrusion, despite being tangible, was not as great as in the case of the single-extruded preparations. Probably, changes evoked in starch after the first extrusion were so significant that further degradation in an extruder did not result in such a significant increase of water solubility. In addition, starch solubility in water turned out to be considerably affected by temperatures of both extrusion processes. It was increasing along with the increasing temperatures of both extrusion processes. According to Lai \& Kokini [1991, all the parameters related both to the raw material and to extruder's geometry as well as the process itself are jointly responsible for the changes occurring in preparations after the process of extrusion. Factors, which, according to these authors, have the greatest effect on water solubility of preparations are parameters that determine the time the raw material remains inside the extruder, namely raw material's moisture content, process temperature and the rotation speed of the screw. Singh \& Smith [1997] include additionally fat content of the material into the factors having the most significant influence on solubility. When considering each of the above-mentioned elements separately, it has been stated that process temperatures exert the greatest effect on solubility [Lai \& Kokini, 1991; Singh \& Smith, 1997; Nabeshima \& Grossmann, 2001]. Majority of authors in their research have also recorded an increased solubility of preparations occurring along with an increasing temperature of the extrusion process [Guha et al., 1997; Singh \& Smith, 1997; Nabeshima \& Grossmann, 2001; Ziobro et al., 2002; Singh et al., 2007]. Such a tendency may be observed when examining the solubility of modified preparations produced in the second extrusion process [Chinnaswamy et al., 1989].

Tables 3 and 4 present the values of water absorption capacity of starch obtained during single- and double-extrusion determined at a temperature of $30^{\circ} \mathrm{C}$ and $80^{\circ} \mathrm{C}$. At both measurement temperatures, the value of water absorption capacity was significantly affected by the temperatures of the first and second extrusion. The increased temperature of the first extrusion process contributed to a reduced average water absorption capacity. The lowest content of water bound by $1 \mathrm{~g}$ of starch was characteristic to starch extruded at a temperature of $140-150-170^{\circ} \mathrm{C}(2.78 \mathrm{~g}$ water/g starch - when determined at a temperature of $30^{\circ} \mathrm{C}$ and $0.76 \mathrm{~g}$ water $/ \mathrm{g}$ starch - when determined at $80^{\circ} \mathrm{C}$ ), whereas the highest content of water was bound by starch extruded at the lowest temperature $\left(4.32 \mathrm{~g}\right.$ water $/ \mathrm{g} \mathrm{starch}-$ at $30^{\circ} \mathrm{C}$ and $2.63 \mathrm{~g}$ water/g starch at $80^{\circ} \mathrm{C}$ ). The highest mean value of this parameter was recorded when examining single-extruded starch (6.91 g water/g starch - at $30^{\circ} \mathrm{C}$ and $2.87 \mathrm{~g}$ water $/ \mathrm{g}$ starch - at $80^{\circ} \mathrm{C}$ ). Water absorption capacity of starch subjected to the process of second extrusion decreased significantly. The extrusion at a temperature of $90-100-120^{\circ} \mathrm{C}$ resulted in twice as low content of the bound water $\left(3.07 \mathrm{~g}\right.$ water $/ \mathrm{g}$ starch - at $30^{\circ} \mathrm{C}$ and $1.50 \mathrm{~g}$ water/g starch - at $80^{\circ} \mathrm{C}$ ). Statistically the lowest value of water absorption capacity was reported for the preparations produced at the higher temperature of the second extrusion process, the mean value of this parameter was almost sixfold lower in relation to the single-extruded starch. Similar were also findings of other scientists, who took no account of wa- 
TABLE 3. Water absorption capacity at the temperature of $30^{\circ} \mathrm{C}$ of preparations obtained in single and double extrusion process.

\begin{tabular}{|c|c|c|c|c|c|}
\hline \multicolumn{6}{|c|}{ Water absorption capacity at the temperature of $30^{\circ} \mathrm{C}\left(\mathrm{g}_{\text {water }} / \mathrm{g}_{\text {starch }}\right)$} \\
\hline \multirow{2}{*}{ Temperature of first extrusion process } & & \multicolumn{2}{|c|}{ Temperature of second extrusion process } & \multirow{2}{*}{\multicolumn{2}{|c|}{ Mean }} \\
\hline & & $90-100-120^{\circ} \mathrm{C}$ & $140-150-170^{\circ} \mathrm{C}$ & & \\
\hline $50-60-70^{\circ} \mathrm{C}$ & 7.79 & 3.65 & 1.53 & 4.32 & \\
\hline $90-100-120^{\circ} \mathrm{C}$ & 6.99 & 3.47 & 0.86 & 3.77 & $\mathrm{NIR}=0.59$ \\
\hline $140-150-170^{\circ} \mathrm{C}$ & 5.95 & 2.09 & 0.31 & 2.78 & \\
\hline Mean & 6.91 & 3.07 & 0.90 & & \\
\hline & & $\mathrm{NIR}=0.60$ & & & \\
\hline
\end{tabular}

NIR of interaction $=0.86$

TABLE 4. Water absorption capacity at the temperature of $80^{\circ} \mathrm{C}$ of preparations obtained in single and double extrusion process.

\begin{tabular}{|c|c|c|c|c|c|}
\hline \multicolumn{6}{|c|}{ Water absorption capacity at the temperature of $80^{\circ} \mathrm{C}\left(\mathrm{g}_{\text {water }} / \mathrm{g}_{\text {starch }}\right)$} \\
\hline \multirow{2}{*}{ Temperature of first extrusion process } & & \multicolumn{2}{|c|}{ Temperature of second extrusion process } & \multirow{2}{*}{\multicolumn{2}{|c|}{ Mean }} \\
\hline & & $90-100-120^{\circ} \mathrm{C}$ & $140-150-170^{\circ} \mathrm{C}$ & & \\
\hline $50-60-70^{\circ} \mathrm{C}$ & 4.64 & 2.64 & 0.61 & 2.63 & \\
\hline $90-100-120^{\circ} \mathrm{C}$ & 2.68 & 1.18 & 0.53 & 1.46 & $\mathrm{NIR}=0.44$ \\
\hline $140-150-170^{\circ} \mathrm{C}$ & 1.28 & 0.67 & 0.32 & 0.76 & \\
\hline \multirow[t]{2}{*}{ Mean } & 2.87 & 1.50 & 0.49 & & \\
\hline & & $\mathrm{NIR}=0.3$ & & & \\
\hline
\end{tabular}

NIR of interaction $=0.70$

TABLE 5. Flow behaviour index calculated from Ostwald de Waele rheological model for flow curves of pastes made from starch obtained in single and double extrusion process.

\begin{tabular}{|c|c|c|c|c|c|}
\hline \multicolumn{6}{|c|}{ Flow behaviour index ( ) } \\
\hline \multirow{2}{*}{ Temperature of first extrusion process } & & \multicolumn{2}{|c|}{ Temperature of second extrusion process } & \multirow{2}{*}{\multicolumn{2}{|c|}{ Mean }} \\
\hline & & $90-100-120^{\circ} \mathrm{C}$ & $140-150-170^{\circ} \mathrm{C}$ & & \\
\hline $50-60-70$ & 0.71 & 0.80 & 0.82 & 0.78 & \\
\hline $90-100-120^{\circ} \mathrm{C}$ & 0.64 & 0.71 & 0.90 & 0.75 & $\mathrm{NIR}=0.06$ \\
\hline $140-150-170^{\circ} \mathrm{C}$ & 0.68 & 0.76 & 0.90 & 0.78 & \\
\hline Mean & 0.68 & 0.76 & 0.87 & & \\
\hline & & $\mathrm{NIR}=0.0$ & & & \\
\hline
\end{tabular}

ter solubility in their experiments [Guha et al., 1997; Jamroz et al., 1998; González \& Pérez, 2002]. The above discussed changes in water solubility of the preparations occurring after the extrusion process are probably due to the same changes proceeding in the structure of starch granules, which also contributed to the increased solubility.

All the pastes were non-Newtonian fluids, which was indicated by the flow behaviour index determined with the Ostwald de Waele rheological model, which at each of the examined cases took the value below 1 (from 0.64 to 0.90 , Table 5). The statistical analysis demonstrated that the temperatures of the first extrusion process had no significant effect on the value of this parameter. In contrast, the flow behaviour index was found to be statistically significantly affected by the temperature of the second extrusion process. The mean value of this parameter at the lower temperature of the second process of extrusion was 0.76 , whilst the pastes made from starch extruded at the higher temperatures of the second extrusion were characterised by its higher value (0.87). Also, in the case of the coefficient of consistency (Table 6) and plastic viscosity calculated by means of the Casson rheological model (Table 7), the only factor diversifying the produced preparations to a statistically significant extent was the process of second extrusion and its temperatures. The second extrusion process resulted in a considerable decrease in the value of the consistency coefficient compared to the single-extruded starch. The only parameter which increased after the process of extrusion was the value of yield stress (Table 8). The most resistant to shearing were the pastes made from single-extruded starch, whose yield stress value reached 3.06 $\mathrm{Pa}$. The statistical analysis demonstrated that the process of second extrusion decreased significantly the value of the examined parameter. In turn, no statistically significant effect on the examined parameter was recorded for process temperatures. 
TABLE 6. Coefficient of consistency calculated from Ostwald de Waele rheological model for flow curves of pastes made from starch obtained in single and double extrusion process.

\begin{tabular}{|c|c|c|c|c|c|}
\hline \multicolumn{6}{|c|}{ Coefficient of consistency $\left(\mathrm{Pa} \cdot \mathrm{s}^{\mathrm{n}}\right)$} \\
\hline \multirow{2}{*}{\multicolumn{2}{|c|}{ Temperature of first extrusion process }} & \multicolumn{2}{|c|}{ Temperature of second extrusion process } & \multirow{2}{*}{\multicolumn{2}{|c|}{ Mean }} \\
\hline & & $90-100-120^{\circ} \mathrm{C}$ & $140-150-170^{\circ} \mathrm{C}$ & & \\
\hline $50-60-70^{\circ} \mathrm{C}$ & 0.59 & 0.24 & 0.21 & 0.35 & \\
\hline $90-100-120^{\circ} \mathrm{C}$ & 1.88 & 0.56 & 0.11 & 0.85 & $\mathrm{NIR}=0.32$ \\
\hline $140-150-170^{\circ} \mathrm{C}$ & 0.79 & 0.55 & 0.11 & 0.48 & \\
\hline \multirow[t]{2}{*}{ Mean } & 1.09 & 0.45 & 0.14 & & \\
\hline & & $\mathrm{NIR}=0.2$ & & & \\
\hline
\end{tabular}

NIR of interaction $=0.44$

TABLE 7. Plastic viscosity calculated from Casson rheological model for flow curves of pastes made from starch obtained in single and double extrusion process.

\begin{tabular}{|c|c|c|c|c|c|}
\hline \multicolumn{6}{|c|}{ Casson plastic viscosity $(\mathrm{Pa} \cdot \mathrm{s})$} \\
\hline \multirow{2}{*}{\multicolumn{2}{|c|}{ Temperature of first extrusion process }} & \multicolumn{2}{|c|}{ Temperature of second extrusion process } & \multirow{2}{*}{\multicolumn{2}{|c|}{ Mean }} \\
\hline & & $90-100-120^{\circ} \mathrm{C}$ & $140-150-170^{\circ} \mathrm{C}$ & & \\
\hline $50-60-70^{\circ} \mathrm{C}$ & 0.104 & 0.077 & 0.079 & 0.087 & \\
\hline $90-100-120^{\circ} \mathrm{C}$ & 0.163 & 0.082 & 0.089 & 0.111 & $\mathrm{NIR}=0.036$ \\
\hline $140-150-170^{\circ} \mathrm{C}$ & 0.146 & 0.095 & 0.087 & 0.109 & \\
\hline \multirow[t]{2}{*}{ Mean } & 0.138 & 0.085 & 0.085 & & \\
\hline & & $\mathrm{NIR}=0.03$ & & & \\
\hline
\end{tabular}

NIR of interaction $=0.049$

TABLE 8. Yield stress calculated from Casson rheological model for flow curves of pastes made from starch obtained in single and double extrusion process.

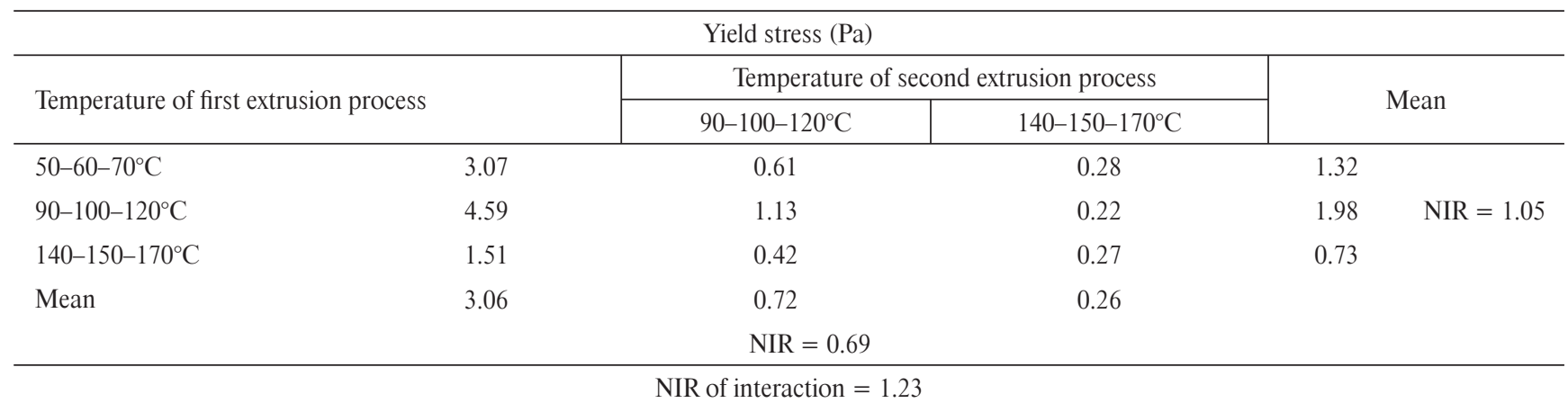

The results of the conducted research indicate that during the process of extrusion a number of factors have a statistically significant effect on the parameters describing rheological properties of the produced preparations. Factors which enhance starch degradation during the process of extrusion, e.g.: the value of mechanical energy during the process (SME), moisture content of the extruded samples, the value of pressure inside the extruder or the temperature of the extrusion process, exert the greatest effects in this respect [Della Valle et al., 1995; Śmietana et al., 1996; Alves et al., 1999]. The increased values of the above-mentioned parameters result in a reduced viscosity of the preparations [Willett et al., 1997]. According to Alves and coworkers [Alves et al., 1999], the reduced viscosity due to increasing temperature may be explained by intensive degradation of starch chains. After the extrusion process, the shorter chains of amylose and amylopectin in starch form networks, in which the number of intramolecular bonds is significantly decreased. The yield point is strictly connected to the number of intramolecular bonds being formed and disrupted. During shearing a sample with an increasing speed, the speed of disruption of the existing intermolecular bonds exceeds the speed of their re-formation, which consequently leads to a decreased resistance of starch pastes to shearing, which is manifested by decreasing values of the coefficient of consistency and yield stress. In the pastes made from extruded starch, the number of bonds that might be formed between starch chains in pastes was probably significantly diminished, which should also decrease the value of this parameter [Alves et al., 1999].

After the second extrusion process, values of all the examined parameters describing the rheological characteris- 
tics of pastes were observed to decrease, except for the flow behaviour index whose value after this process remained unchanged. The material obtained after the second extrusion was characterised by an even greater reduction of starch chain length compared to the single-extruded preparations. This successive shortening of chains in the preparations obtained after the second process of extrusion simplifies the structure of the networks formed in the pastes even to a greater extent. In these poorly developed networks the number of intramolecular interactions and, thus, their total force is considerably smaller, which leads to a decreased plastic viscosity of the resultant pastes. Reduced interactions between starch chains in pastes might also decrease the value of yield stress [Berski et al., 2000; Bhandari et al., 2002].

High water solubility of starch preparations obtained during the process of double-extrusion and a low value of their viscosity might find potential applications in the food industry. In the future, preparations from double-extruded starch might be applied as a component of the so-called "convenient food", e.g. soup concentrates, sauces, spice mixes etc. A great advantage of starch modified with such a method is its high solubility at low temperatures. This quality may appear very desirable to producers of easy-to-prepare food for children, which owing to the presence of thermolabile ingredients cannot be prepared at high temperatures. These preparations, due to their high solubility at room temperature and low viscosity, might also be used as an addition to pomace juices. Presumably, a small addition of starch modified with this method would enrich the impression of a full taste of these juices.

\section{CONCLUSIONS}

1. Properties of potato starch subjected to the process of double extrusion were different from the properties of single-extruded starch. From the conducted research it results that the extent and direction of these changes were dependent on the number of the conducted extrusion processes and their temperatures.

2. Each successive process of extrusion and elevation of process temperatures resulted in a statistically significant increase of water solubility of the preparations determined in water as "cold-soluble" and "hot-soluble" and in a decrease of their water absorption capacity.

3. Double-extruded potato starch was characterised by lowered values of rheological properties of pastes in relation to pastes made from single-extruded starch, yet these changes did not depend on temperatures of the first extrusion process.

4. There was no statistically significant effect of the temperature values of each of the extrusion processes on the properties of the examined starch.

\section{REFERENCES}

1. Alves R.M.L., Grossmann M.V.E., Silva R.S.S.F., Gelling properties of extruded yam (Dioscorea alata) starch. Food Chem., 1999, 67, 123-127.
2. Berski W., Kołodziej Z., Golachowski A., Modification of potato starch with various phosphorus contents with the extrusion method. Zeszyty Naukowe Akademii Rolniczej w Krakowie, 2000, 367, 5-15 (in Polish).

3. Bhandari P.N., Singhal R.S., Kale D.D., Effect of succinylation on rheological profile of starch pastes. Carbohydr. Polym., 2002, 47, 365-371.

4. Chinnaswamy R., Hanna M.A., Zobel H.F., Microstructural, physiochemical, and macromolecular changes in extrusioncooked and retrograded corn starch. Cereal Foods World, 1989, 34, 415-422.

5. Della Valle G., Boché Y., Colonna P., Vergnes B., The extrusion behaviour of potato starch. Carboh. Polym., 1995, 28, 255-264.

6. Drożdż W., Tomaszewska-Ciosk E., Rheological properties of potato starch pastes with the addition of kaolin. Pol. J. Food Nutr. Sci., 2007, 4A, 113-117.

7. Gambuś H., Golachowski A., Bala - Piasek A., Ziobro R., Nowotna A., Surowka K., Functional Properties of starch extrudates. Part 1. Dependence o extrudates properties on starch water content. EJPAU, 1999, Food Science and Technology, 2.

8. Ganjyal G.M., Hanna M.A., Effects of Extruder Die Nozzle Dimensions on Expansion and Micrographic Characterization During Extrusion of Acetylated Starch. Starch, 2004, 56, 108-117.

9. González R.J., Torres R.L., de Greef D.M., Guadalupe B.A., Effects of extrusion conditions and structural characteristics on melt viscosity of starchy materials. J. Food Eng., 2006, 74, 96-107.

10. González Z., Pérez E., Evaluation of lentil starches modified by microwave irradiation and extrusion cooking. Food Res. Int., 2002, 35, 415-420.

11. Guha M., Ali S.Z., Bhattacharya S., Twin-screw extrusion of rice flour without a die: Effect of barrel temperature and screw speed on extrusion and extrudate characteristics. J. Food Eng., 1997, 32, 251-267.

12. Hagenimana A., Ding X.L., Fang T., Evaluation of rice flour modified by extrusion cooking. J. Cereal Sci., 2006, 43, 38-46.

13. Jamroz J., Ciesielski W., Pielichowski K., Tomasik P., Extrusion-cooking of potato starch and selected properties of the extrudates Pol. J. Food Nutr. Sci., 1998, 1, 88-97.

14. Kollengode A.N., Sokhey A.S., Hanna M.A., Physical and molecular properties of re-extruded starches as affected by extruder screw configuration. J. Food Sci., 1996, 61, 596-600.

15. Kőksel H., Ryu G.H., Basman A., Demiralp H., Ng P.K.W., Effects of extrusion variables on the properties of waxy hulless barley extrudates. Nahrung Food, 2004, 1, February, 19-24.

16. Lai L.S., Kokini J.L., Physicochemical changes and rheological properties of starch during extrusion (a review). Biotechnol. Prog., 1991, 7, 251-266.

17. Nabeshima E.H., Grossmann M.V.E., Functional properties of pregelatinized and cross-linked cassava starch obtained by extrusion with sodium trimetaphosphate. Carboh. Polym., 2001, 45, 347-353.

18. Richter M., Augustat S., Schierbaum F., Ausgewählte Methoden der Stärkechemie, VEB Fachbuchverlag Leipzig 1968.

19. Rzedzicki Z., Zarzycki P., Effect of extrusion process of maize-oat mixtures on changes in fraction composition of dietary fibre. Żywność. Nauka. Technologia. Jakość., 2005, 4, 62-73 (in Polish). 
20. Singh B., Sekhon K.S., Singh N., Effects of moisture, temperature and level of pea grits on extrusion behaviour and product characteristics of rice. Food Chem., 2007, 100, 198-202.

21. Singh N., Smith A.C., A comparison of wheat starch, whole wheat meal and oat flour in the extrusion cooking process. J. Food Eng., 1997, 34, 15-32.

22. Sun T., Laerke H.N., Jørgensen H., Knudsen K.E.B., The effect of extrusion cooking of different starch sources on the in vitro and in vivo digestibility in growing pigs. Anim. Feed Sci. Tech. 2006, 131, 66-85.

23. Śmietana Z., Szpendowski J., Soral-Śmietana M., Świgoń J., Modification of potato starch by extrusion. Acta Acad. Agricult. AC Tech. Olst., Technologia Alimentorum, 1996, 29, 3-13.

24. Thymi S., Krokida M.K., Pappa A., Maroulis Z.B., Structural properties of extruded corn starch. J. Food Eng., 2005, 68, 519-526.
25. Willett J.L., Millard M.M., Jasberg B.K., Extrusion of waxy maize starch: melt rheology and molecular weight degradation of amylopectin. Polymer, 1997, 38, 5983-5989.

26. Wójtowicz A., Influence of some functional components addition on the microstructure of precooked pasta. Pol. J. Food Nutr. Sci., 2005, 4, 417-422.

27. Zięba T, Kapelko M., Jecewicz K., Styczyńska M., Properties of extruded starch modified with phosphorus and glycin. Pol. J. Food Nutr. Sci., 2007, 4C, 633-638.

28. Ziobro R., Nowotna A., Golachowski A., Gambuś H., Hernik M., Sabat R., The influence of extruder's temperature profile on the characteristics of processed starch. Żywność. Nauka. Technologia. Jakość., 2002, 4. Suppl., 242-248.

Received December 2010. Revisions received April and July 2011. Accepted July 2011. Published on-line on the 28 ${ }^{\text {th }}$ of March 2012. 


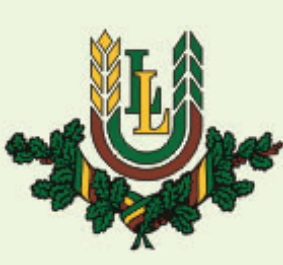

Latvia University of Agriculture

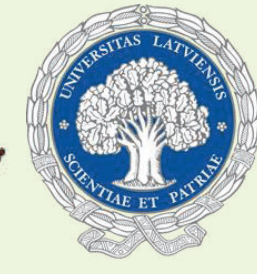

University of Latvia

\section{RIGAS STRADIN̦A UNIVERSITĀTE}

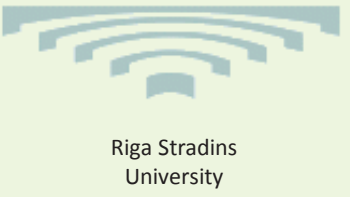

Dear colleagues,

Three biggest universities of Latvia which are jointly implementing inter - university masters study program: "Study program of master of health sciences in nutrition science" are glad to invite you to the International Conference "Nutrition and Health". Conference will take place in Riga, Latvia, from 4 to 6 September 2012. The Conference will also provide a forum for disseminating and gathering ideas and research results by leading scientists, government, as well as business leaders in food, nutrition and health.

We are looking forward to welcome you in Riga! Organizing Committee

\section{Programme}

The Conference will include invited lectures, oral presentations, posters and exhibition of food industry product and publications.

\section{Topics}

1. Nutrition policy. Public health and epidemiology.

2. Nutrition science.

- Human physiology and nutrition.

- Assessment of nutrition and metabolism.

- Metabolic syndrome and basic principles of medical nutrition therapy.

- Nutrition in disease prophylaxis.

3. Nutrition during human life.

- Basic principles of nutrition regulation in women in various periods of life.

- Nutrition of children and adolescents.

- Nutrition of elderly.

- Nutrition and mouth health.

- Nutrition in physical and emotional stress.

4. Clinical nutrition science.

- Nutrition for prevention and treatment of immune deficiency and genetic disorders.

- Medical nutrition in the treatment of chronic diseases.

- Medical nutrition in the treatment of acute diseases.

- Nutrition psychology and neurotic eating disorders.

5. New and functional food.

- New food and genetically modified organisms.

- Quality of food and nutrition.

- Nutrition supplements and food additives.

- Nutrition value of food products.

\section{Conference languages}

The official languages of the Conference will be English.

\section{Call for papers}

Abstracts (up to 200 words) for oral and poster presentation to be sent through the abstract submission form (available at the official web site) or by e-mail to the Conference organizing committee.

\section{INTERNATIONAL CONFERENCE}

\section{«NUTRITION AND HEALTH»}

Riga, Latvia,

September 4-6, 2012

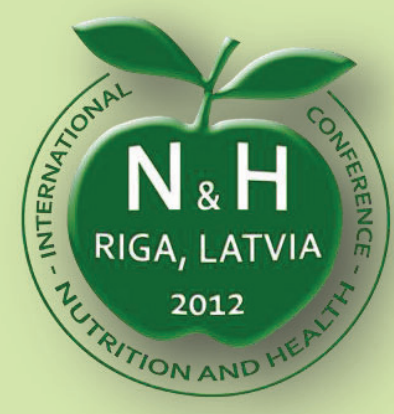

\section{Deadlines}

- March 12, 2012, Abstract submission.

- April 2, 2012, Acceptance notification for authors.

- April 16, 2012, Transmission of the manuscript.

- June 18, 2012, Acceptance of the manuscript.

\section{Registration fees}

Full registration fee

Full Students fee

Students, nutrition specialists

(without paper)

$\begin{array}{cc}\text { before July } 1^{\text {st }} & \text { after July } 1^{\text {st }} \\ 200 € & 250 € \\ 100 € & 150 € \\ 50 € & 75 €\end{array}$

VAT included
Full registration fee covers: admission to all scientific sessions and exhibitions; full set of Conference materials and Book of Abstracts (including oral and poster presentations) and Proceedings of the Latvian Academy of Sciences Section B. with Articles (www.versita.com), and social activities (welcome cocktail, coffee during the breaks, lunch, conference dinner). Conference Proceedings will be published before the Conference.

\section{Payment for participants}

More information see in official Conference website.

\section{Accommodation}

For all Conference participants there will be available accommodation at Radisson BLU Hotel Latvia, more information about accommodation and travel see in official Conference website.

\section{Web Site}

All information about the "Nutrition and health» conference can also be found on the official Conference website: http://www.lu.lv/nutritionandhealth/

\section{Conference chair}

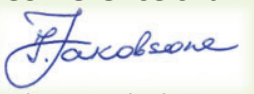

Ida Jākobsone, Asoc.prof. University of Latvia; Representative of EuCheMS Food Chemistry Division in Latvia E-mail: nutritionandhealth@lu.lv 